\title{
Efficacy of Vaginal Misoprostol versus Sublingual Misoprostol in the Management of Early Miscarriage
}

\author{
NAILA EHSAN ${ }^{1}$, MARYAM SHOAIB ${ }^{2}$, ROHANA SALAM ${ }^{3}$, SAKINA NAEEM ${ }^{4}$, SAMIA SAIFULLAH \\ ${ }^{1}$ Professor, ${ }^{2,4}$ Assistant Professors, ${ }^{3}$ Associate Professor, ${ }^{5}$ Senior Registrar, \\ Department of Obstetrics \& Gynaecology, Sandeman Provincial Hospital, Quetta \\ Correspondence to Prof. Naila Ehsan Chauhan e-mail: nailaehsan1@gmail.com Cell 0333-7809717
}

\begin{abstract}
Aim: To compare the effectiveness of vaginal with sublingual misoprostol in the management of early miscarriage. Study Design: Randomized controlled trial

Place and Duration of Study: Department of Gynaecology and Obstetrics, Unit-I, Sandeman Provincial Hospital Quetta from $1^{\text {st }}$ February 2018 to $31^{\text {st }}$ July2018.

Methodology: One hundred and eleven patients with clinical diagnosis of missed miscarriage confirmed by ultrasound receiving per vaginal misoprostol $(800 \mu \mathrm{g})$ were named as group " $A$ " and those receiving sublingual misoprostol were labeled as group "B". Clinical outcome was assessed as the complete expulsion of the products of conception either successful or unsuccessful confirmed by a repeat pelvic ultrasound after the treatment.

Results: The mean age of patients in group-A was $25.89 \pm 5.7$ years and in the group-B was a $26.38 \pm 5.5$ year. The mean gestational age in group-A was $9.44 \pm 1.58$ weeks and in group-B was a $9.45 \pm 1.52$ week. The overall miscarriage rate was $67.5 \% .72 \%$ of women in group-B and $63 \%$ in the group-A had complete miscarriage. The mean induction to expulsion interval was 13.55 hours in group-A and 13.22 hours in group-B. The rate of complete expulsion of products of conception was high in group- A compared to the group- B.

Conclusion: Sublingual misoprostol is as effective as vaginal misoprostol in management of the early miscarriage.

Key words: Miscarriage, Misoprostol, vaginal, sublingual
\end{abstract}

\section{INTRODUCTION}

Early miscarriage is a major health problem worldwide with an incidence of $15-20 \%$. In Pakistan 890,000 women annually present with missed or incomplete miscarriage with an annual miscarriage rate of 29 per 1000 women aged 15-49 years ${ }^{1}$. Management of early miscarriage includes expectant, medical and surgical. Traditionally the primary treatment for early miscarriage has been Dilatation and Curettage (DNC). DNC is though considered safe in the hands of skilled personnel but requires a trained personnel, operating room and an anesthetist ${ }^{2}$. Recent studies have questioned the need for routine DNC suggesting that medical management might be more appropriate ${ }^{3,4}$.

Medical management using misoprostol is a safe and cost effective method for early miscarriage having a high level of patient satisfaction ${ }^{4}$ and a success rate around $80 \%{ }^{5}$ Misoprostol is a synthetic prostaglandin $E_{1}$ analogue available in the form of tablets administered through oral, sublingual, rectal and vaginal routes, with a reported effectiveness of $85 \%$ with vaginal route $^{6}$. Sublingual route is though associated with more side effects, most common of which is an unpleasant taste but has a success rate of $95 \%$ and is more convenient, avoids painful vaginal administration and gives more privacy ${ }^{7}$.

Nonsurgical alternatives expand a woman's treatment options and, in turn, the quality of care. ${ }^{8}$ Moreover, in some settings, surgical options are not available to women or are not medically feasible. In first trimester abortion, combined treatment by misoprostol with mifepristone appears to be

Received on 25-05-2019

Accepted on 15-01-2020 more effective than misoprostol-alone regimens and thus are considered the gold standard for medical induction. However, misoprostol-alone regimens may be the treatment of choice in settings in which mifepristone is not available or is too costly ${ }^{9}$.

Medical management of missed abortion is less practiced in our area because of doubts regarding its efficacy. Similarly sublingual route of administration is also less popular due to the same reason though Sublingual route is gaining popularity worldwide. Considering the magnitude of early miscarriage and the clinical burden on hospitals in our setup the authors wanted to conduct this study to remove doubts regarding efficacy of sublingual administration of misoprostol as a cost effective method.

\section{PATIENTS AND METHODS}

This randomized controlled trial study was conducted at Gynaecology and obstetrics department, Unit-I, Sandeman provincial hospital, Quetta from first February 2018 till $31^{\text {st }}$ July 2018. Randomization was done by lottery method. Approval to conduct the study was taken from the medical superintendent of the Sandeman provincial hospital, Quetta. Sample size calculated was 222 (111 for each group), keeping anticipated population proportion for complete uterine evacuation with vaginal misoprostol as $85 \%$ and anticipated population proportion for sublingual misoprostol as $95 \%$, power of test $80 \%$ and level of significance $5 \%$. All the patients having early miscarriage fulfilling the inclusion criteria were included in the study. Patients with suspected ectopic pregnancy, severe anemia $(\mathrm{Hb}<7 \mathrm{~g} / \mathrm{dl})$, severe blood loss at admission soaking $>2$ large pads in an hour for 2 hours in a row, known allergy to prostaglandin, patients with intrauterine contraceptive device, evidence of cardiac, hepatic or renal disease, 
patients with previous caesarean section were excluded from the study to avoid confounding factors and biasness during the study. Informed consent was taken from the patients. Baseline investigations were sent to laboratory for blood complete count, blood grouping, Hepatitis B surface antigen, anti-hepatitis $\mathrm{C}$ antibodies and blood sugar level for optimizing management accordingly. Patient's privacy and comfort were kept in consideration. Patients were given misoprostol vaginally and sublingually by lottery method to remove personal biasness. Patients labeled as Group-A received intra vaginal misoprostol 800 micrograms at the time of admission, in case of failure to abort two further doses of 400 microgram were repeated at 3 hourly intervals. Patients named as Group-B received 600 microgram of misoprostol sublingually and were advised to keep the saliva in mouth until the tablet absorbed. In case of failure to abort or incomplete abortion $400 \mu \mathrm{g}$ misoprostol was repeated at three hourly intervals for a maximum of two doses and a total of three doses. An ultrasound was carried out to confirm uterine evacuation after the patient expelled the products of conception. Cervical status, amount of vaginal blood loss and vitals were monitored. Women with heavy vaginal bleeding and incomplete miscarriage needing emergency surgical evacuation by dilatation and curettage were considered as treatment failure. Women requiring analgesia were given injection tramadol intramuscularly. Following the evacuation all patients were followed for 6 hours for vaginal bleeding and were discharged with advice of follow-up 1 week later. Rhanti $\mathrm{D}$ immunoglobulin was given to Rh-negative women who underwent surgical evacuation on emergency basis due to treatment failure. The data were entered and analyzed on SPSS version 20. For efficacy of both routes of administration of misoprostol as complete evacuation, percentages were calculated and Chi-square test was applied. P-value of $<0.05$ was considered significant.

\section{RESULTS}

A total of 222 patients were included in the study. Onehundred and eleven patients each were included in group$A$ and group- $B$. The mean age of patients in group-A was $25.89 \pm 5.7$ years. The mean age of patients in group- $B$ was $26.38 \pm 5.5$ years. Mean gestational age of subject in vaginal group was $9.44 \pm 1.58$ weeks and in sublingual group $9.45 \pm 1.52$ weeks. Mean gestational age of the study group was $9.4 \pm 1.55$ weeks; mean gestational age in the vaginal group was $9.4 \pm 1.58$ weeks and in the sublingual group was $9.45 \pm 1.52$ weeks. Effect of maternal age, parity and gestational age with the risk of the occurrence of early miscarriage is given in Table 1 .

The miscarriage rate overall was $67.5 \%$. $72 \%$ of women in the sublingual group and $63 \%$ in the vaginal group had complete miscarriage as represented in Table 2. Mean induction to abortion interval was 13.55 hours in vaginal group and 13.22 hours in sublingual group. No statistical difference between the outcome of miscarriage and induction to abortion interval was observed between the sublingual and vaginal group.
Table 1: The demographic characteristics of the women diagnosed with early miscarriage

\begin{tabular}{|l|c|c|c|}
\hline Variables & $\begin{array}{c}\text { Vaginal } \\
\text { Misoprostol } \\
\mathrm{n}=111\end{array}$ & $\begin{array}{c}\text { Sublingual } \\
\text { Misoprostol } \\
\mathrm{n}=111\end{array}$ & p-value \\
\hline $\begin{array}{l}\text { Mean Age } \\
\text { (years) }\end{array}$ & $25.89 \pm 5.7$ & $26.38 \pm 5.52$ & 0.36 \\
\hline $\begin{array}{l}\text { Parity, median } \\
\text { (range) }\end{array}$ & $3.29 \pm 0.51$ & $3.33 \pm 0.58$ & 0.41 \\
\hline $\begin{array}{l}\text { Mean gestational } \\
\text { age (Weeks) }\end{array}$ & $9.44 \pm 1.58$ & $9.45 \pm 1.52$ & 0.17 \\
\hline
\end{tabular}

Table 2: Comparison of efficacy between vaginal with sublingual misoprostol in the treatment of early miscarriage

\begin{tabular}{|l|c|c|c|}
\hline $\begin{array}{l}\text { Complete } \\
\text { miscarriage }\end{array}$ & $\begin{array}{c}\text { Vaginal } \\
\text { Misoprostol } \\
\mathrm{n}=111\end{array}$ & $\begin{array}{c}\text { Sublingual } \\
\text { Misoprostol } \\
\mathrm{n}=111\end{array}$ & Total \\
\hline $\begin{array}{l}\text { Successful } \\
\text { (Efficacy Yes) }\end{array}$ & $70(63.06 \%)$ & $80(72.07 \%)$ & $150(67.56 \%)$ \\
\hline $\begin{array}{l}\text { Unsuccessful } \\
\text { or required } \\
\text { DNC (Efficacy } \\
\text { No) }\end{array}$ & $41(36.94 \%)$ & $31(27.93 \%)$ & $72(32.43 \%)$ \\
\hline
\end{tabular}

\section{DISCUSSION}

With the availability of prostaglandins in the early 1970s, medical termination has become an alternative method for managing the early pregnancy miscarriage and misoprostol is the drug of choice worldwide ${ }^{10,11}$. Misoprostol is a potent uterotonic agent, stable at room temperature and is considerably cheaper, thus cost-effective for our low economic resource setup with high environmental temperature ${ }^{12}$.

Most of the cases were between 19 to 30 years of age in both groups. Mean age, gravidity, parity and gestational age were not significant between groups. Vaginal misoprostol of 800ug was recommended for missed miscarriage by the NICE and some clinical guidelines. ${ }^{13}$ In this study rate of successfully complete miscarriage was $72.07 \%$ in sublingual group and $63.06 \%$ in vaginal group with no statistical difference between the two routes $(p<0.5)$.Similar is true about induction to abortion interval. Treatment failure needing surgical evacuation was required in about $30 \%$ of cases in sublingual group versus $40 \%$ in vaginal group.

The results of the study are comparable to a study from Bahawalpur which reported a success rate of $73.3 \%$ in sublingual group and $66.7 \%$ in vaginal group ${ }^{14}$. However it is much less comparable to similar studies reported from China and India which used $600 \mu \mathrm{gm}$ of sublingual and vaginal misoprostol and reported an overall success rate of $87.5 \%$ and $86 \%$ respectively. ${ }^{15}$ This higher success rate may be related to the higher dose $600 \mathrm{ugm}$ of misoprostol used in those studies. According to the Systematic Review of the Cochrane database, sublingual misoprostol is as effective as vaginal misoprostol in causing complete miscarriage but is associated with more frequent diarhhoea. ${ }^{16}$ More frequent side effects with sublingual use of misoprostol are due to its high peak concentration and great bioavai 


\section{CONCLUSION}

In conclusion, sublingual $600 \mu \mathrm{g}$ or vaginal $800 \mu \mathrm{g}$ misoprostol is a non-invasive, effective and safe agent so it can be used for management of early pregnancy loss. Sublingual route of administration is as effective as vaginal group, with more convenient dosage and privacy and side effects that are easily manageable.

\section{REFERENCES}

1. Bano K, Talat, lqbal S. Alternative to surgical evacuation of uterus; misoprostol for post abortion care. J Surg Pak (Int).2009.14:53-7

2. Farooq F, Javed L, Mumtaz A, Naveed N. Comparison of manual vaccum aspiration and dilatation curettage in the treatment of early pregnancy failure. J Ayub Med Coll Abbotabad. 2011; 23(3):28-31

3. Atarod Z, Talebi F, Hashemi SA, Kheradmand A. Comparison of vaginal misoprostol application versus curettage in treatment of early pregnancy failure: a randomization clinical trial study. Afr $\mathrm{J}$ Pharm Pharmacol. $2013 ; 7(20): 1339-42$

4. Shah N, Azam SI, Khan NH. Sublingual versus vaginal misoprostol in the management of missed miscarriage. J Pak Med Assoc .2010;60(2):113-6

5. Shoaib AA, Alharazi AH. Medical versus surgical termination of the first trimester missed miscarriage. AMJ.2013;49(1):13-6

6. Allen R, O'Brien BM. Use of misoprostol in obstetrics and gyneacology. Rev Obstet Gynecol. 2009;2(3):15968.

7. Jalil S, Nausheen S, Akhter AZ. Sublingual misoprostol in the management of first trimester miscarriage. Pak $\mathrm{J}$ Surg.2010;26(2):169-73

8. Sotiriadis A, Makrydimas G, Papatheodorou S, loannidis JP. Expectant, medical, or surgical management of first-trimester miscarriage: a metaanalysis. Obstet Gynecol. 2005; 105:1104-8.

9. Sotiriadis A, Makrydimas G, Papatheodorou S, loannidis JP. Expectant, medical, or surgical management of first-trimester miscarriage: a metaanalysis. Obstet Gynecol. 2005; 105:1104-8.

10. Child TJ, Thomas J, Rees M, Mac Kenzie I.Z. Morbidity of first trimester aspiration termination and the seniority of the surgeon. Hum Reprod 2001;16,875-8.

11. Nabendu BHATTACHARJEE, Shayama Prasad SAHA, Samir Chandra GHOSHORY, et al. A randomized comparative study on sublingual versus vaginal administration of misoprostol for termination of pregnancy between 13 to 12 weeks. Australian and New Zealand journal of obstetrics and gynecology. Vol 48, issue 2, April 2008, 165-71.

12. Medical methods for first trimester abortion. Kulier R et al. Cochrane database systemic review, 2011.

13. National institute for health and care excellence guidelines. Ectopic pregnancy and miscarriage Diagnosis and initial management. www.nice.org.uk/guidance/cg154(2012)

14. Tang, O.S, Schweer,H., Seybeth,H.W et al. Pharmacodynamics of different routes of administration of misoprostol. Human Reprod 2018; $17,332-6$.

15. Latif S, Usmani SY, Fatima N. Comparison of Sublingual and Vaginal Misoprostol in Termination of First Trimester Missed Abortion. Pak J Med Health Sci .2014; 8(2)

16. Sharma D, Singhal SR, Rani $X X$, Sublingual misoprostol in management of missed abortion in India. Trop Doct 2007; 37: 39-40.

17. Neilson JP, Hickey M, Vazquez J, Medical treatment for early fetal death (less than 24 weeks). Cochrane Database Syst Rev 2006; 3: CD002253.I 